\title{
Gender-Related Effects on Substrate Utilization and Metabolic Adaptation in Hairless Spontaneously Hypertensive Rat
}

\author{
J. TRNOVSKÁ ${ }^{1,2}$, J. ŠILHAVÝ ${ }^{3}$, V. ZÍDEK ${ }^{3}$, M. ŠIMÁKOVÁ ${ }^{3}$, P. MLEJNEK ${ }^{3}$, V. LANDA ${ }^{3}$, \\ S. EIGNER ${ }^{4,5}$, K. EIGNER HENKE ${ }^{3}$, V. ŚKOP ${ }^{2}$, O. OLIYARNYK ${ }^{2}$, L. KAZDOVÁ ${ }^{2}$, \\ T. MRÁČEK ${ }^{3}$, J. HOUŠTĚK ${ }^{3}$, M. PRAVENEC ${ }^{3}$
}

${ }^{1}$ Department of Veterinary Sciences, Faculty of Agrobiology, Food and Natural Resources, Czech University of Life Sciences, Prague, Czech Republic, ${ }^{2}$ Center for Experimental Medicine, Institute for Clinical and Experimental Medicine, Prague, Czech Republic, ${ }^{3}$ Institute of Physiology, Academy of Sciences of the Czech Republic, Prague, Czech Republic, ${ }^{4}$ Nuclear Physics Institute, Academy of Sciences of the Czech Republic, Husinec-Řež, Czech Republic, ${ }^{5}$ Faculty of Pharmacy, Charles University in Prague, Hradec Králové, Czech Republic

Received May 5, 2014

Accepted July 29, 2014

On-line September 5, 2014

\begin{abstract}
Summary
Cold exposure of rats leads to ameliorated glucose and triglyceride utilization with females displaying better adaptation to a cold environment. In the current study, we used hairless rats as a model of increased thermogenesis and analyzed genderrelated effects on parameters of lipid and glucose metabolism in the spontaneously hypertensive (SHR) rats. Specifically, we compared hairless coisogenic SHR-Dsg4 males and females harboring mutant Dsg4 (desmoglein 4) gene versus their SHR wild type controls. Two way ANOVA showed significant Dsg4 genotype (hairless or wild type) $x$ gender interaction effects on palmitate oxidation in brown adipose tissue (BAT), glucose incorporation into BAT determined by microPET, and glucose oxidation in skeletal muscles. In addition, we observed significant interaction effects on sensitivity of muscle tissue to insulin action when Dsg4 genotype affected these metabolic traits in males, but had little or no effects in females. Both wild type and hairless females and hairless males showed increased glucose incorporation and palmitate oxidation in BAT and higher tissue insulin sensitivity when compared to wild type males. These findings provide evidence for gender-related differences in metabolic adaptation required for increased thermogenesis. They are consistent with the hypothesis that increased glucose and palmitate utilization in BAT and muscle is associated with higher sensitivity of adipose and muscle tissues to insulin action.
\end{abstract}

\section{Key words}

Gender • Hairless rat • Metabolism • Brown adipose tissue

\section{Corresponding author}

M. Pravenec, Institute of Physiology, Academy of Sciences of the Czech Republic, Vídeňská 1083, 14220 Prague 4, Czech Republic. E-mail: pravenec@biomed.cas.cz

\section{Introduction}

Recently, it has been demonstrated that brown adipose tissue (BAT) in mice exposed to cold plays an important role in triglyceride and glucose utilization and thus prevents obesity, ectopic fat accumulation, and associated metabolic disturbances (Bartelt et al. 2011, 2012). These studies and recent findings that BAT is retained in humans into adulthood (Virtanen et al. 2009) and that its abundance is greatly diminished in obese individuals (Vijgen et al. 2011) increased the interest to study the BAT metabolism as a potential mechanism for reducing the risk factors for the metabolic syndrome, obesity, and type 2 diabetes. In addition, it has been reported that, similar to rodents, human BAT is stimulated by cold exposure (Farmer 2009, Orava et al. 2011, Chen et al. 2013). The spontaneously hypertensive rat (SHR) is the most widely used animal model of

PHYSIOLOGICAL RESEARCH • ISSN 0862-8408 (print) • ISSN 1802-9973 (online)

(c) 2015 Institute of Physiology v.v.i., Academy of Sciences of the Czech Republic, Prague, Czech Republic

Fax +420 241062 164, e-mail: physres@biomed.cas.cz, www.biomed.cas.cz/physiolres 
essential hypertension and under special environmental conditions also develops disturbances of lipid and glucose metabolism (Pravenec et al. 2014). However, the role of BAT in the pathogenesis of metabolic disturbances in the SHR remains unknown. In addition, significant gender related metabolic differences have been reported in rats exposed to cold temperature (Gabaldon et al. 1995, Rodriguez et al. 2001). Genetically hairless strains of rodents represent rewarding models to study adaptive thermogenesis as exemplified by the nu/nu mice. Standard ambient temperature of $22{ }^{\circ} \mathrm{C}$ lies well below thermoneutrality for such animals, due to the diminished insulating capacity (Weihe 1984). This translates into the chronic requirement for increased adaptive thermogenesis. The objective of the current study was to analyze the effects of hairless phenotype on BAT and parameters of lipid and glucose metabolism in SHR males compared to SHR females. Specifically, we compared hairless males and females from the coisogenic SHR-Dsg4 strain that harbors mutated Dsg4 (desmoglein 4) gene (Meyer et al. 2004) versus their wild type SHR controls. Our results demonstrate significant Dsg4 genotype x gender interaction effects on glucose and lipid utilization in BAT and on sensitivity of muscle tissue to insulin action.

\section{Materials and Methods}

\section{Animals}

The spontaneously hypertensive rat (SHR/Ola) and the hairless coisogenic SHR/Ola-Dsg4 strain with mutated Dsg4 (desmoglein 4) gene caused by C-to-T transition generating a premature termination codon within exon 8 (Meyer et al. 2004) were obtained from the Institute of Physiology, Academy of Sciences of the Czech Republic. The Dsg4 mutation was originally found in the SHR.BN-chr.1 congenic strain and was transferred on the SHR genetic background by backcross breeding. We studied male and female rats at the age of 4 months fed ad libitum standard laboratory chow $(\mathrm{N}=8-10$ per group). All female rats were nulliparous and in metestrus. Animals were housed at $22{ }^{\circ} \mathrm{C}$ with $12: 12$ hour light:dark cycle. Tissues were collected from rats in postprandial state. All experiments were performed in agreement with the Animal Protection Law of the Czech Republic and were approved by the Ethics Committee of the Institute of Physiology, Academy of Sciences of the Czech Republic, Prague.

\section{Food consumption}

We measured daily food intake in each group by subtracting the amount of food remaining in the cage from the measured amount of food provided each day. The average daily food intake for each group was then calculated by averaging all of the daily intake measurements obtained over the entire course of the study.

Basal and insulin stimulated glycogen synthesis in muscle

For ex vivo measurement of insulin stimulated incorporation of glucose into glycogen, diaphramatic muscles were incubated for $2 \mathrm{~h}$ in $95 \% \mathrm{O}_{2}+5 \% \mathrm{CO}_{2}$ in Krebs-Ringer bicarbonate buffer, $\mathrm{pH} 7.4$, containing $0.1 \mu \mathrm{Ci} / \mathrm{ml}$ of ${ }^{14} \mathrm{C}-\mathrm{U}$ glucose, $5 \mathrm{mmol} / 1$ of unlabeled glucose, and $2.5 \mathrm{mg} / \mathrm{ml}$ of bovine serum albumin (Fraction V, Sigma-Aldrich, St. Louis, MO, USA), with or without $250 \mu \mathrm{U} / \mathrm{ml}$ insulin. Glycogen was extracted, and insulin stimulated incorporation of glucose into glycogen was determined.

\section{Glucose oxidation in muscle}

Glucose oxidation was determined ex vivo in diaphragmatic muscle by measuring the incorporation of [U- $\left.{ }^{14} \mathrm{C}\right]$ glucose into $\mathrm{CO}_{2}$ according to Vrána et al. (1978). Skeletal muscle was immediately incubated for $2 \mathrm{~h}$ in Krebs-Ringer bicarbonate buffer, $\mathrm{pH} 7.4$ that contained $5.5 \mathrm{mM}$ unlabeled glucose, $0.5 \mu \mathrm{Ci} / \mathrm{ml}$ of $\left[\mathrm{U}_{-}{ }^{14} \mathrm{C}\right]$ glucose (UVVR, Prague, Czech Republic), and $3 \mathrm{mg} / \mathrm{ml}$ bovine serum albumin. After $2 \mathrm{~h}$ incubation, $0.3 \mathrm{ml}$ of $1 \mathrm{M}$ hyamine hydroxide was injected into the central compartment of the incubation vial and $0.5 \mathrm{ml}$ of $1 \mathrm{M} \mathrm{H}_{2} \mathrm{SO}_{4}$ was added to the main compartment to liberate $\mathrm{CO}_{2}$. The vials were incubated for another $30 \mathrm{~min}$, the hyamine hydroxide was then quantitatively transferred to the scintillation vial containing $10 \mathrm{ml}$ of toluene-based scintillation fluid for counting of radioactivity.

\section{Glucose utilization in isolated white adipose tissue}

Pieces of male epididymal fat and female parametrial fat were rapidly dissected and incubated for $2 \mathrm{~h}$ in Krebs-Ringer bicarbonate buffer with $5 \mathrm{mmol} / \mathrm{l}$ glucose, $0.1 \mu \mathrm{Ci}\left[\mathrm{U}_{-}{ }^{14} \mathrm{C}\right]$ glucose/ml (UVVR, Prague, Czech Republic) and $2 \%$ bovine serum albumin, gaseous phase $95 \% \mathrm{O}_{2}$ and $5 \% \mathrm{CO}_{2}$ in the presence $(250 \mu \mathrm{U} / \mathrm{ml})$ or absence of insulin in incubation media. All incubations were performed at $37{ }^{\circ} \mathrm{C}$ in sealed vials in a shaking water bath. Then we estimated incorporation of $\left[\mathrm{U}_{-}{ }^{14} \mathrm{C}\right]$ 
glucose into neutral lipids. Briefly, fat was removed from incubation medium, rinsed in saline, and immediately put into chloroform. The pieces of tissue were dissolved using a Teflon pestle homogenizer, methanol was added (chloroform:methanol 2:1), and lipids were extracted at $4{ }^{\circ} \mathrm{C}$ overnight. The remaining tissue was removed, $\mathrm{KH}_{2} \mathrm{PO}_{4}$ was added and a clear extract was taken for further analysis. An aliquot was evaporated, reconstituted in scintillation liquid, and the radioactivity measured by scintillation counting. Incremental glucose utilization was calculated as the difference between the insulin stimulated and basal incorporation of glucose into neutral lipids.

Lipolysis in isolated epididymal and parametrial adipose tissue

For measurement of basal and adrenaline stimulated lipolysis, pieces of epididymal and parametrial adipose tissue were incubated in Krebs-Ringer phosphate buffer containing $3 \%$ bovine serum albumin (Fraction V, Sigma-Aldrich) at $37^{\circ} \mathrm{C}, \mathrm{pH} 7.4$ with or without adrenaline $(0.25 \mu \mathrm{g} / \mathrm{ml})$. The tissue was incubated for $2 \mathrm{~h}$ and the concentrations of NEFA and glycerol in the medium were determined.

\section{Palmitate oxidation in BAT}

Palmitate oxidation was measured in Krebs-Ringer bicarbonate buffer with $0.5 \mu \mathrm{Ci} / \mathrm{ml}$ of ${ }^{14} \mathrm{C}$-palmitic acid complexed with bovine serum albumin ( $3 \mathrm{mg} / \mathrm{ml}$, fraction $\mathrm{V}$, Sigma-Aldrich) and $0.3 \mu \mathrm{mol} / \mathrm{ml}$ nonradioactive palmitic acid. The incubation was carried out at $37^{\circ} \mathrm{C}$ in sealed vials in a shaking water bath. After a 2-h incubation, $0.2 \mathrm{ml}$ of $1 \mathrm{M}$ hyamine hydroxide was injected into the central compartment of vessel and $0.5 \mathrm{ml}$ of $1 \mathrm{M} \mathrm{H}_{2} \mathrm{SO}_{4}$ was injected into the main compartment containing incubation medium to liberate $\mathrm{CO}_{2}$. The vessels were incubated for additional $45 \mathrm{~min}$. The hyamine hydroxide was then quantitatively transferred to the scintillation vial for radioactivity counting. Results are expressed as nmol palmitate/g/h.

\section{Biochemical analyses}

Blood glucose levels were measured by the glucose oxidase assay (Erba-Lachema, Brno, Czech Republic) using tail vein blood drawn into $5 \%$ trichloracetic acid and promptly centrifuged. NEFA (nonesterified fatty acid) levels were determined using an acyl-CoA oxidase-based colorimetric kit (Roche Diagnostics GmbH, Mannheim, Germany). Serum triglyceride concentrations were measured by standard enzymatic methods (Erba-Lachema, Brno, Czech Republic). Serum insulin concentrations were determined using the Mercodia Rat Insulin ELISA kit (Mercodia AB, Uppsala, Sweden).

\section{${ }^{18}$ F-FDG imaging of BAT}

The $\mu$ PET imaging was performed on an Albira $\mu$ PET/CT system (Bruker BioSpin, Ettlingen, Germany). During PET/CT measurements anesthetized (3\% Isoflurane in oxygen) animals (females: 200-250 g body weight; males: 300-350 g body weight) were placed head first in prone position. Offset was set at $85 \mathrm{~mm}$ to place the BAT in the field of view of the PET scanner. $30-40 \mathrm{MBq}$ of ${ }^{18} \mathrm{~F}-\mathrm{FDG}$ in $0.4-0.7 \mathrm{ml} \quad 0.9 \% \mathrm{NaCl}$ solution were administered as a bolus via a previously inserted catheter in the tail vein. $\mu$ PET/CT scans were performed at $60 \mathrm{~min}$ post injection. Optical reconstruction and estimation of volumes of interest (VOI's) and VOI statistics were performed using PMOD (PMOD Technologies Ltd., Zürich, Switzerland). VOI's were drawn manually around the BAT in the neck of the animals. VOI statistics were used for comparative analysis.

\section{Gene expression}

Samples of BAT tissue were snap-frozen and stored in liquid nitrogen. The total RNA was isolated using the Trizol reagent (Life Technologies, New York, USA). Subsequently, $0.5 \mu \mathrm{g}$ of RNA was reversetranscribed with the SCRIPT cDNA Synthesis Kit (Jena Bioscience, Jena, Germany), using a mixture of oligo-dT and random hexamer primers in the total volume of $10 \mu \mathrm{l}$ according to the manufacturer's protocol. The resulting cDNA was diluted 5 times and used as a template for quantitative PCR performed on the ViiA 7 instrument (Life Technologies) with 5x HOT FIREPol Probe qPCR Mix Plus chemistry (Solis Biodyne, Tartu, Estonia). The following predesigned TaqMan gene expression assays (Life Technologies) were used for gene quantification: Ucpl (uncoupling protein 1) (Rn00562126_m1), Cidea (cell death-inducing DFFA-like effector a) (Rn04181355_m1), Pparg (peroxisome proliferator-activated receptor gamma) (Rn00440945_m1), Dio2 (deiodinase, iodothyronine, type II) (Rn00581867_m1), and B2m (beta-2 microglobulin) (Rn00560865_m1). The following conditions were used for quantitative PCR: $15 \mathrm{~min}$ at $95^{\circ} \mathrm{C}$ followed by 45 cycles of denaturation at $95^{\circ} \mathrm{C}$ for 
$15 \mathrm{~s}$ and annealing/elongation at $60^{\circ} \mathrm{C}$ for $1 \mathrm{~min}$. All samples were normalized to the $B 2 m$ values and the results expressed as fold changes of cycle threshold $(\mathrm{Ct})$ value relative to controls using the $2-\Delta \Delta \mathrm{Ct}$ formula. Calibration curves for all genes were created by 10 -fold dilution of a mixed cDNA sample to verify amplification efficiency.

\section{Statistical analysis}

SigmaPlot ${ }^{\circledR} 12$ software package was used for two way ANOVA to test for Dsg4 genotype x gender interactions. For variables showing evidence of Dsg4 genotype $\mathrm{x}$ gender interaction effects, we used Holm Sidak testing that adjusts for multiple comparisons to determine whether the effects of chronic mild cold exposure were significant in males and females. Results are expressed as means \pm SEM.

\section{Results}

\section{Body weight and adiposity}

First we compared the effect of hairless phenotype on body weight and adiposity assessed as perirenal fat depo weight (Table 1). Wild type males exhibited significantly higher body weight and adiposity when compared to hairless males whereas in females, no significant differences between hairless and wild type animals were observed. In contrast, there were no significant differences in relative weight of BAT among all groups (Tables 1 and 2).

\section{Glucose and palmitate utilization in BAT and muscle tissue}

We determined the metabolic activity of BAT and muscles to determine tissues responsible for enhanced thermogenesis in hairless animals. Two way ANOVA showed significant Dsg4 genotype x gender interaction effects on glucose uptake into BAT determined by microPET, which serves as a measure of BAT activation as increased glycolysis implicates that mitochondrial substrate oxidation is utilized for heat production via the action of uncoupling protein 1 (Fig. 1, Table 2). Furthermore, differences were also observed on palmitate oxidation in BAT (Fig. 2A, Table 2) as well as on glucose oxidation in muscle (Fig. 2B, Table 2). Wild type males exhibited significantly lower palmitate oxidation and glucose uptake by BAT when compared to hairless males or wild type and hairless females. Glucose oxidation in muscles in wild type males was significantly lower when compared to hairless males whereas both wild type and hairless females exhibited significantly higher glucose oxidation in muscle when compared to males (Fig. 2, Table 2). Thus it seems that requirement for enhanced adaptive thermogenesis leads to the induction of nonshivering thermogenesis in BAT as well as to increased muscle metabolic activity in males while none of these adaptations is present in females, which possess already high thermogenic capacity as wild types. Increased muscle metabolic activity may indicate partial involvement of muscle in the adaptive nonshivering thermogenesis in Dsg4 males and females in general.

Sensitivity to insulin action in muscle and white adipose tissue

Two way ANOVA showed significant Dsg4 genotype $\mathrm{x}$ gender interaction effects on sensitivity of muscle to insulin action. As can be seen in Figure 3, wild type males exhibited significantly lower sensitivity of muscles to insulin action when compared to hairless males. Both wild type and hairless females showed significantly higher sensitivity of muscle tissue when compared to males but wild type females did not differ significantly from hairless females (Fig. 3, Table 2). The observation that Dsg4 genotype affected sensitivity of muscle tissue to insulin action in males, but had little or no effects in females, is consistent with the idea that requirement for increased adaptive thermogenesis can lead to changes in muscle insulin sensitivity that is dependent on gender. There were significant gender effects on insulin stimulated lipogenesis with females showing significantly higher incorporation of glucose into adipose tissue lipids. However, there were no significant interactions with the $\mathrm{Dsg} 4$ genotype for this trait (Fig. 3). In addition, wild type males showed significantly higher basal lipolysis when compared to hairless males and females while there were no significant differences among all 4 groups in adrenalin stimulated lipolysis (Tables 1 and 2). There were significant gender effects on serum glucose, insulin and triglycerides when females showed significantly higher serum insulin and triglycerides and lower glucose levels. Serum NEFA levels tended to be reduced in hairless males and both hairless and wild type females when compared to wild type males but the difference did not achieve statistical significance (Tables 1 and 2). 
Table 1. Biochemical and metabolic parameters in wild type and hairless mutant SHR rats.

\begin{tabular}{|c|c|c|c|c|}
\hline Trait & $\begin{array}{l}\text { TSHR } \\
(\mathrm{N}=8)\end{array}$ & $\begin{array}{l}\text { TेSHR hairless } \\
\qquad(\mathrm{N}=8)\end{array}$ & $\begin{array}{l}q \mathbf{S H R} \\
(\mathrm{N}=8)\end{array}$ & $\begin{array}{l}+ \text { SHR hairless } \\
\qquad(\mathrm{N}=10)\end{array}$ \\
\hline Body weight $(g)$ *\#ץ & $372 \pm 6^{\pi}$ & $330 \pm 11^{\S *}$ & $197 \pm 5$ & $207 \pm 4$ \\
\hline $\begin{array}{l}\text { Food consumption } \\
\text { (g/100 g body weight/day) }\end{array}$ & $10.6 \pm 1.3$ & $11.1 \pm 1.5$ & $11.1 \pm 1.3$ & $11.5 \pm 1.5$ \\
\hline $\begin{array}{l}\text { Relative weight of perirenal fat } \\
(\mathrm{g} / 100 \mathrm{~g} \text { body weight }) *^{* t}\end{array}$ & $0.53 \pm 0.04^{\top}$ & $0.30 \pm 0.04^{\S}$ & $0.32 \pm 0.03$ & $0.32 \pm 0.04$ \\
\hline $\begin{array}{l}\text { Relative weight of interscapular } \\
B A T \text { (g/100 g body weight) }\end{array}$ & $0.094 \pm 0.006$ & $0.099 \pm 0.004$ & $0.099 \pm 0.006$ & $0.090 \pm 0.003$ \\
\hline Serum glucose $(\mathrm{mmol} / \mathrm{ll})^{\dagger}$ & $6.4 \pm 0.3$ & $6.9 \pm 0.1$ & $5.6 \pm 0.2^{*}$ & $5.2 \pm 0.2$ \\
\hline Serum triglycerides $(\mathrm{mmol} / \mathrm{l})^{\dagger}$ & $0.80 \pm 0.06^{\mathbb{\pi}}$ & $0.77 \pm 0.04^{\ddagger}$ & $1.03 \pm 0.08$ & $1.15 \pm 0.09$ \\
\hline Serum NEFA (mmol/l) & $0.64 \pm 0.03$ & $0.50 \pm 0.03$ & $0.53 \pm 0.07$ & $0.50 \pm 0.04$ \\
\hline Serum insulin $(\mathrm{nmol} / \mathrm{l})^{\dagger}$ & $0.085 \pm 0.012^{q}$ & $0.106 \pm 0.02^{\ddagger}$ & $0.262 \pm 0.023$ & $0.214 \pm 0.028$ \\
\hline Basal lipolysis (NEFA $\mu \mathrm{mol} / \mathrm{g}) *^{\dagger}$ & $2.77 \pm 0.18^{\pi}$ & $2.01 \pm 0.26$ & $1.32 \pm 0.28$ & $1.83 \pm 0.25$ \\
\hline $\begin{array}{l}\text { Adrenaline stimulated lipolysis } \\
\text { (NEFA } \mu \mathrm{mol} / \mathrm{g})\end{array}$ & $6.19 \pm 0.42$ & $6.67 \pm 0.47$ & $6.26 \pm 0.54$ & $6.20 \pm 0.37$ \\
\hline
\end{tabular}

Two way ANOVA results: ${ }^{*}$ denotes significant $\mathrm{P}<0.05$ hairless (chronic cold exposure) $\mathrm{x}$ gender interaction - the effects of chronic cold exposure are different in males vs. females. ${ }^{\#}$ denotes $\mathrm{P}<0.05$ significance of wild type vs. hairless; ${ }^{\dagger}$ denotes $\mathrm{P}<0.05$ significance of gender (males vs. females). For comparisons vs. controls Holm Sidak testing was used: ${ }^{\S}$ denotes $\mathrm{P}<0.05$ significance of comparisons for hairless vs. wild type within males; " denotes $\mathrm{P}<0.05$ significance of comparisons between wild type males vs. wild type females; ${ }^{\ddagger}$ denotes $\mathrm{P}<0.05$ significance of comparisons between hairless males and hairless females.

Table 2. Summary of two way ANOVA results.

\begin{tabular}{|c|c|c|c|}
\hline \multirow[b]{2}{*}{ Trait } & \multicolumn{3}{|c|}{ Source of variation } \\
\hline & $\begin{array}{c}\text { Dsg4 } \\
\text { genotype }\end{array}$ & Sex & $\begin{array}{l}\text { Dsg4 x Sex } \\
\text { interaction }\end{array}$ \\
\hline Body weight $(g)$ & + & + & + \\
\hline Relative weight of perirenal fat ( $\mathrm{g} / 100 \mathrm{~g}$ body weight) & + & + & + \\
\hline Relative weight of interscapular BAT ( $\mathrm{g} / 100 \mathrm{~g}$ body weight) & - & - & - \\
\hline Serum glucose (mmol/l) & - & + & - \\
\hline Serum triglycerides (mmol/l) & - & + & - \\
\hline Serum NEFA $(\mathrm{mmol} / \mathrm{l})$ & - & - & - \\
\hline Serum insulin (nmol/l) & - & + & - \\
\hline Basal lipolysis (NEFA $\mu \mathrm{mol} / \mathrm{g})$ & - & + & + \\
\hline Adrenaline stimulated lipolysis (NEFA $\mu \mathrm{mol} / \mathrm{g})$ & - & - & - \\
\hline Basal lipogenesis (nmol glucose/g/2 h) & + & + & - \\
\hline Insulin stimulated lipogenesis (nmol glucose/g/2 h) & - & + & - \\
\hline Basal glycogenesis (nmol glucose/g/2 h) & - & + & - \\
\hline Insulin stimulated glycogenesis (nmol glucose/g/2 h) & - & + & + \\
\hline Palmitate oxidation in BAT (nmol/g/2 h) & + & + & + \\
\hline Glucose oxidation in skeletal muscle (nmol/g/2 h) & - & + & + \\
\hline
\end{tabular}

+ denotes statistically significant $(P<0.05) ;-$ denotes not statistically significant. 

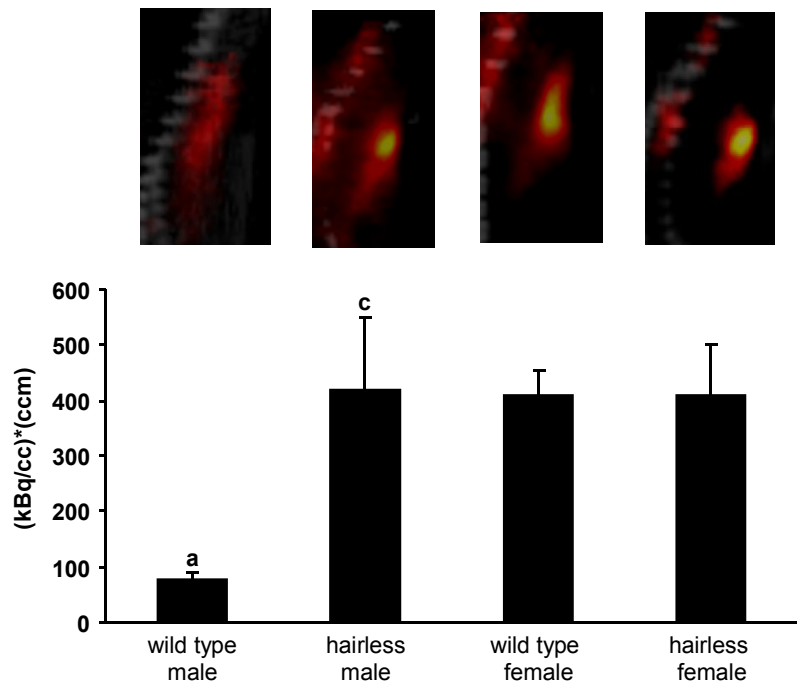

Fig. 1. In vivo microPET imaging of ${ }^{18} \mathrm{~F}$-FDG uptake in BAT. The upper panel shows representative microPET images. The bottom panel shows average values of ${ }^{18} \mathrm{~F}$-FDG uptake in BAT. Two way ANOVA showed significant Dsg4 genotype $\mathrm{x}$ gender interaction effects on ${ }^{18} \mathrm{~F}-\mathrm{FDG}$ uptake in BAT that was significantly reduced in wild type males when compared to hairless males and wild type or hairless females. ${ }^{a}$ denotes significant difference between wild type males and females; 'denotes significant difference between hairless vs. wild type males.

\section{A. Palmitate oxidation in BAT}

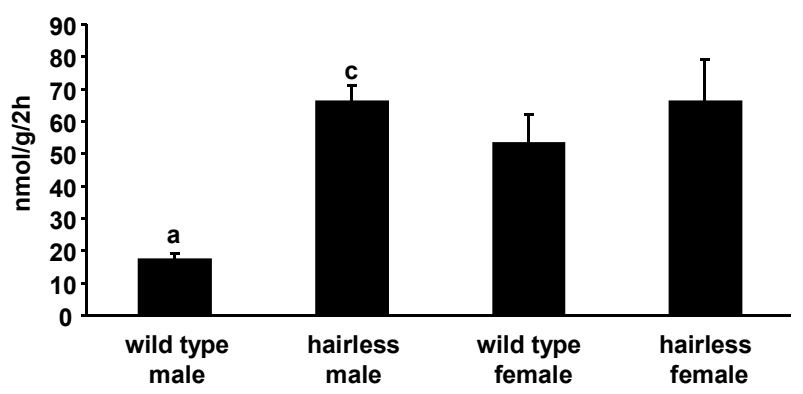

\section{B. Glucose oxidation in skeletal muscle}

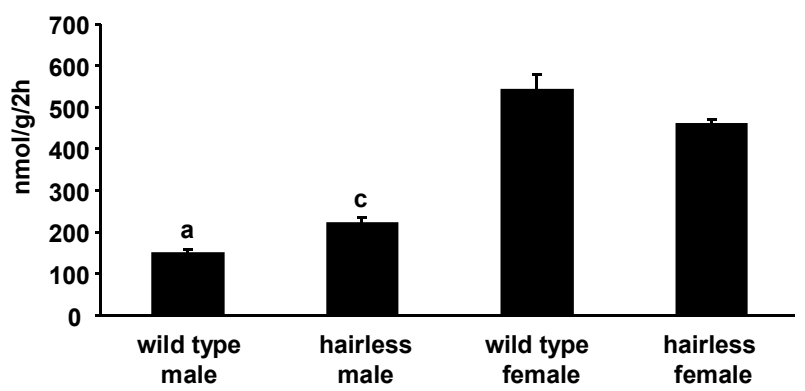

Fig. 2. Effects of chronic mild cold exposure on palmitate oxidation in BAT and glucose oxidation in muscle. A. Two way ANOVA showed significant Dsg4 genotype $\mathrm{x}$ gender interaction on palmitate oxidation in BAT $(\mathrm{P}<0.05)$. B. Two way ANOVA showed significant $D s g 4$ genotype $\mathrm{x}$ gender interaction on glucose oxidation in skeletal muscles $(P=0.003)$. ${ }^{a}$ denotes significant difference between wild type males and females; ${ }^{c}$ denotes significant difference between hairless vs. wild type males.

\section{A. Glycogenesis in skeletal muscle}

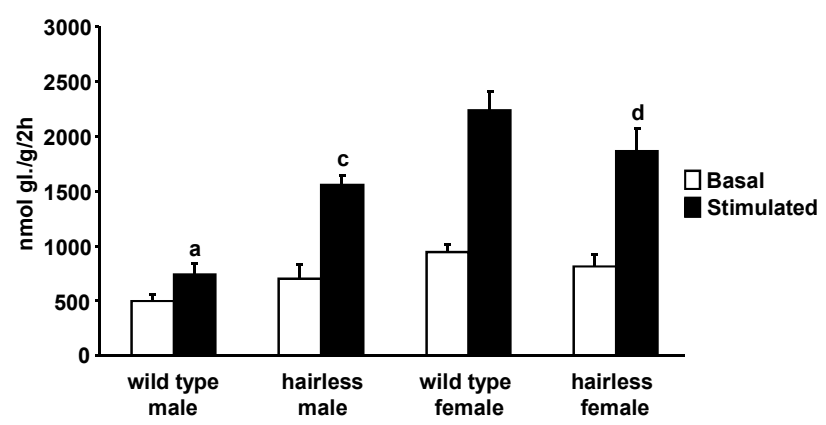

B. Lipogenesis in white adipose tissue

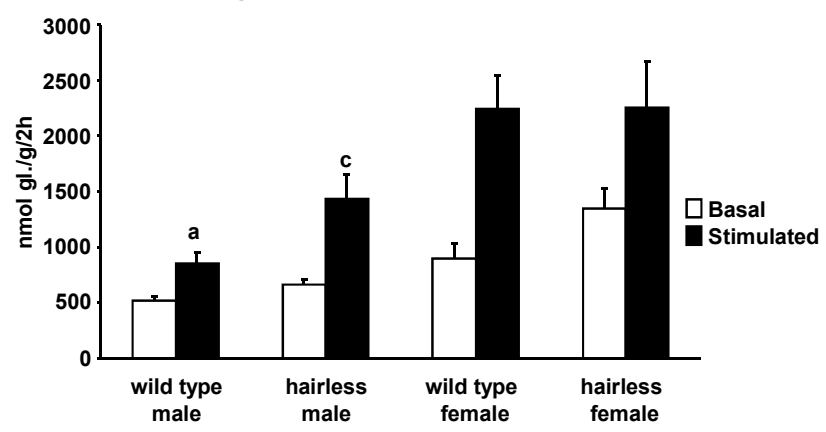

Fig. 3. Sensitivity of muscle and white adipose tissue to insulin action. A. Two way ANOVA showed significant Dsg4 genotype $x$ gender interaction effects on insulin stimulated glycogenesis in muscle $(P=0.002)$. No significant $D s g 4$ genotype $x$ gender interaction effects on basal glycogenesis were observed; males exhibited significant reduced basal glycogenesis when compared to females (significant effect of gender). B. Two way ANOVA revealed significant differences in basal lipogenesis between males and females (effect of gender) and between hairless and wild type rats (effect of Dsg4 genotype). Males exhibited significantly reduced insulin stimulated lipogenesis than females (gender effect). No significant Dsg4 genotype $x$ gender interaction effects on basal or insulin stimulated lipogenesis were observed. ${ }^{a}$ denotes significant difference between wild type males and females; 'denotes significant difference between hairless vs. wild type males; ${ }^{d}$ denotes significant difference between hairless vs. wild type females.

\section{Food consumption}

While the previous data implicate changes in metabolic activity between control and hairless males and between males and females, we did not observe significant differences in food consumption related to $100 \mathrm{~g}$ body weight between hairless and wild type males and females (Table 1).

\section{Gene expression of selected genes in BAT}

Given the observed differences in substrate utilization by BAT tissue, we checked for the expression levels of representative genes to evaluate BAT differentiation status and mitochondrial biogenesis in Dsg4 animals. Figure 4 shows expression of selected genes related to BAT activation status and thermogenic activity. Two way ANOVA identified significant Dsg4 
genotype $\mathrm{x}$ gender interaction effects on expression of Ucp1, Cidea, and Pparg genes but not on Dio2 gene. Thus requirement for higher adaptive thermogenesis in
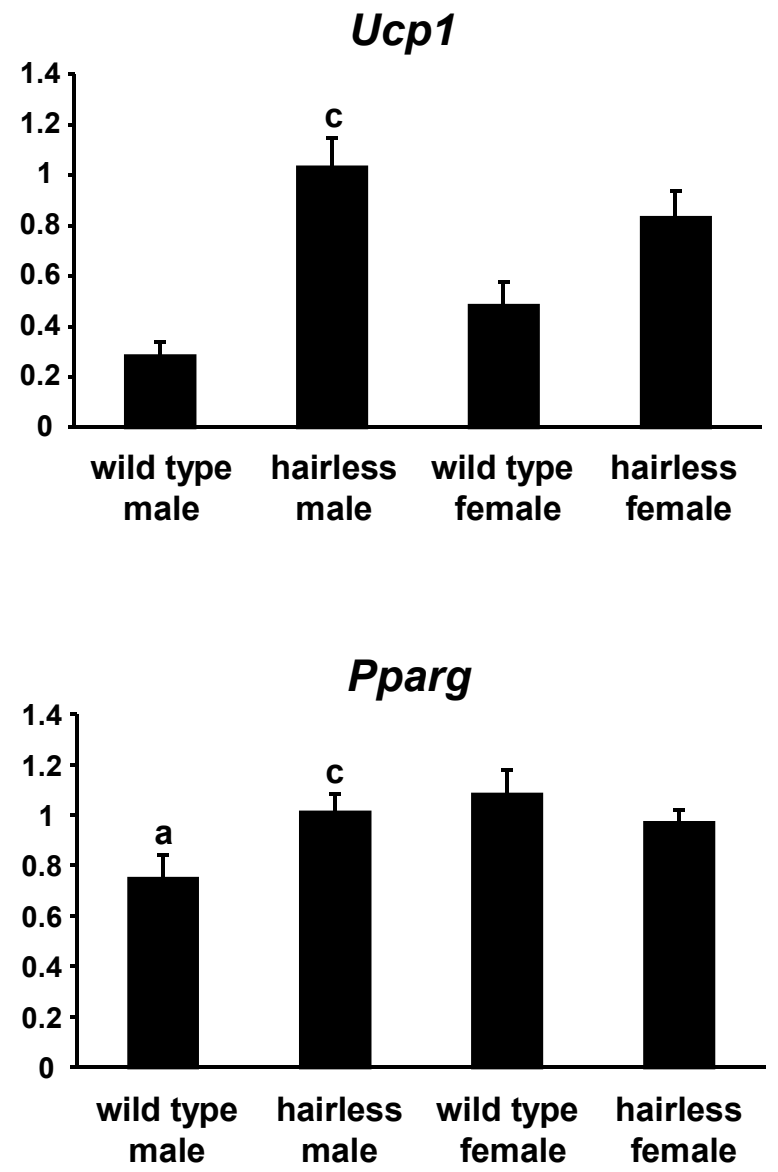

hairless animals is capable to affect expression of Ucp1, Cidea, and Pparg genes in BAT that is dependent on gender.

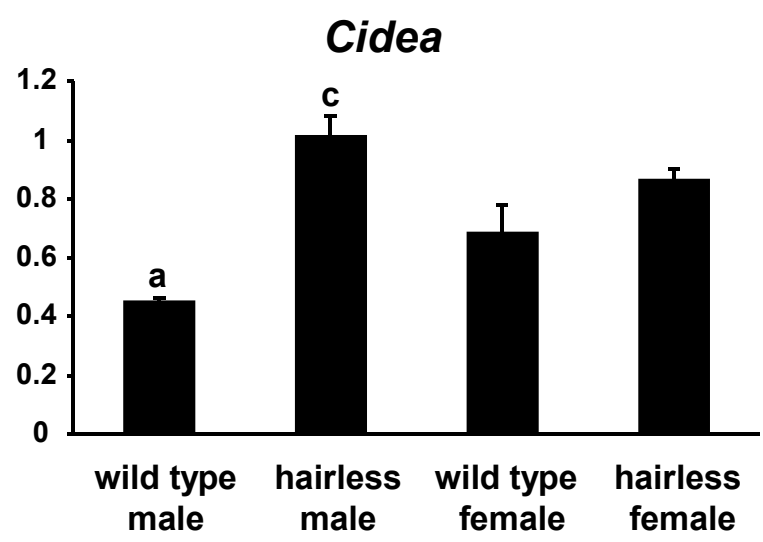

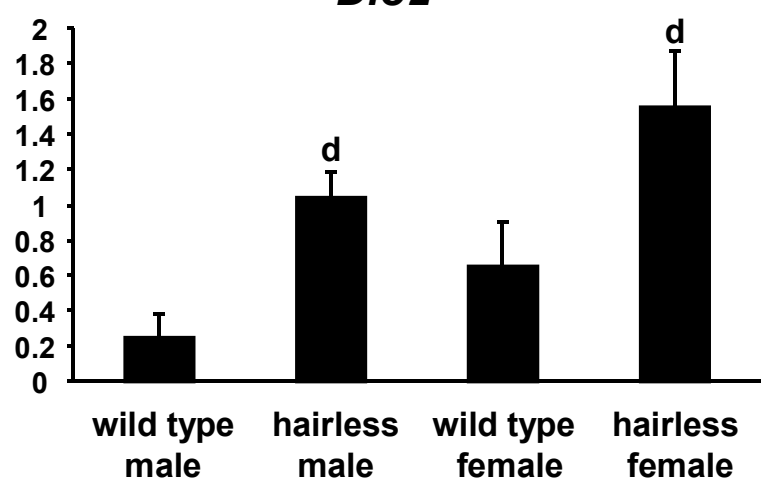

Fig. 4. Expression of selected genes in BAT. Two way ANOVA showed significant Dsg4 genotype $\mathrm{x}$ gender interaction effects on Ucp1, Cidea, and Pparg gene expression in BAT. ${ }^{\text {a }}$ denotes significant difference between wild type males and females; ${ }^{\mathrm{C}}$ denotes significant difference between hairless vs. wild type males. ${ }^{d}$ Wild type vs. hairless rats exhibited significantly reduced expression of Dio 2 gene (effect of Dsg4 genotype).

\section{Discussion}

In the current study, we analyzed gender-related differences in glucose and fatty acid utilization in BAT and parameters of glucose and lipid metabolism in hairless versus wild type SHR male and female rats. Our results revealed significant differences between hairless versus wild type males: significantly increased palmitate oxidation in BAT and glucose uptake into BAT determined with microPET, higher glucose oxidation in muscle, and lower body weight due to reduced adiposity which was associated with increased sensitivity of muscle and visceral adipose tissue to insulin action. On the other hand, hairless females were similar to wild type females in these metabolic parameters. Wild type males when compared to wild type and hairless females exhibited significantly increased adiposity, reduced insulin levels and decreased sensitivity of muscle and WAT to insulin action. In addition, wild type males versus wild type and hairless females showed nearly three-times lower palmitate oxidation in BAT and nearly four-times lower glucose oxidation in muscles. These observations are in agreement with previous reports showing that in female rats BAT is present in greater relative quantities and females have increased BAT thermogenic capacity when compared to males (Smith, 1984, Vallerand et al. 1987, Shibata et al. 1989, Quevedo et al. 1998, RodríguezCuenca et al. 2002, Gasparetti et al. 2003). Studies in ovariectomized rats showed decreased oxidative capacity in mitochondria in BAT and suggested that ovarian hormones are responsible, at least in part, for the sexual dimorphism in BAT mitochondrial function and 
thermogenesis (Nadal-Casellas et al. 2011).

In the current study, we used markers of BAT differentiation and activation - Ucp1, Cidea, Dio2, and Pparg and determined their gene expression profiles in BAT. We found their expression levels to be dependent on gender when it was increased in hairless males and associated with amelioration of metabolic disturbances, while there were no significant differences between hairless and wild type females. Thus it is possible that hairless males adapt the need for higher thermogenesis by the activation of BAT while hairless females do not display such adaptive response. Either the basal BAT activity in females is sufficient to accommodate for increased thermogenesis or they compensate for heat loss by other means such as social thermoregulation observed in hairless mice (Weihe 1984, Houštěk and Holub 1994).

The molecular mechanisms by which differential expression of Ucp1, Cidea, Dio2, and Pparg genes in BAT affect sensitivity of adipose and muscle tissues to insulin action are not fully understood yet. For instance, mice with targeted Ucpl were surprisingly protected against obesity and insulin resistance (Liu et al. 2003) and mice with targeted Cidea gene were also resistant to obesity (Zhou et al. 2003). On the other hand, mice with disrupted Dio2 gene were susceptible to diet-induced obesity and insulin resistance (Marsili et al. 2011). These effects may also be dependent on ambient temperature, as $U c p 1^{-/}$mice kept at thermoneutrality $\left(30^{\circ} \mathrm{C}\right)$ become obese (Feldmann et al. 2009).

In general, our findings on males recapitulate results obtained in hairless mice (Houštěk and Holub 1994, Funda et al. 1998). Both mice and rats do have their thermoneutral temperature at approximately $30{ }^{\circ} \mathrm{C}$ and at $22{ }^{\circ} \mathrm{C}$ they have to compensate for heat loss by thermogenesis (Weihe 1984). This is more profound in hairless animals as their skin insulating capacity accounts for only approximately $50 \%$ of the wild type controls (Hošek et al. 1965). This has to be compensated for by the induction of BAT thermogenesis, accompanied by decrease in circulating triglycerides - main fuel for the BAT thermogenesis. However, no previous studies focused on gender differences in adaptive thermogenesis in nude animals.

Recently, Nookaew et al. (2013) reported that women have higher resting metabolic rate due to increased expression of the UCP1 gene in adipose tissue which suggested an increased number of brown adipocytes when compared with men. In addition, it has been found that women had increased mass of BAT and higher glucose-uptake activity of ${ }^{18} \mathrm{~F}$-FDG incorporation into BAT than men (Kim et al. 2008, Au-Yong et al. 2009, Pfannenberg et al. 2010). These findings support important role of gender-dependent BAT activation and its effects on glucose and lipid metabolism also in humans. It should however be noted, that other studies, while clearly demonstrating that cold acclimation activates BAT and increases nonshivering thermogenesis also in humans, failed to observe sex differences either before or after cold acclimation (van der Lans et al. 2013).

In conclusion, results of the current studies provide evidence for gender-related differences in inducing adaptive thermogenesis and suggest that increased glucose and palmitate utilization in BAT may be associated with higher sensitivity of visceral adipose tissue and muscle to insulin action.

\section{Conflict of Interest}

There is no conflict of interest.

\section{Acknowledgements}

This work was supported by grants 13-04420S and 14-36804G from the Grant Agency of the Czech Republic, LL1204 (within the ERC CZ program) from the Ministry Education, Youth and Sports of the Czech Republic, by grant NT 14325-3/2013 from the Ministry of Health of the Czech Republic, and by grant MH CZ DRO (Institute for Clinical and Experimental Medicine IKEM, IN 0002301). We would like to thank Radiomedic Ltd. (Husinec-Řež, Czech Republic), a subsidiary company of the Institute of Nuclear Physics, Academy of Sciences of the Czech Republic, for kind donation of ${ }^{18}$ F-FDG.

\section{References}

AU-YONG IT, THORN N, GANATRA R, PERKINS AC, SYMONDS ME: Brown adipose tissue and seasonal variation in humans. Diabetes 58: 2583-2587, 2009.

BARTELT A, HEEREN J: The holy grail of metabolic disease: brown adipose tissue. Curr Opin Lipidol 23: 190-195, 2012. 
BARTELT A, BRUNS OT, REIMER R, HOHENBERG H, ITTRICH H, PELDSCHUS K, KAUL MG, TROMSDORF UI, WELLER H, WAURISCH C, EYCHMÜLLER A, GORDTS PL, RINNINGER F, BRUEGELMANN K, FREUND B, NIELSEN P, MERKEL M, HEEREN J: Brown adipose tissue activity controls triglyceride clearance. Nat Med 17: 200-205, 2011.

CHEN KY, BRYCHTA RJ, LINDERMAN JD, SMITH S, COURVILLE A, DIECKMANN W, HERSCOVITCH P, MILLO CM, REMALEY A, LEE P, CELI FS: Brown fat activation mediates cold-induced thermogenesis in adult humans in response to a mild decrease in ambient temperature. J Clin Endocrinol Metab 98: E1218E1223, 2013.

FARMER SR: Obesity: Be cool, lose weight. Nature 458: 839-840, 2009.

FELDMANN HM, GOLOZOUBOVA V, CANNON B, NEDERGAARD J: UCP1 ablation induces obesity and abolishes diet-induced thermogenesis in mice exempt from thermal stress by living at thermoneutrality. Cell Metab 9: 203-209, 2009.

FUNDA DP, HOUŠTĚK J, HOLUB M, KAZDOVÁ L, MICHALSKÝ M, BURÝŠEK L, ČERVINKOVÁ M, ŠÍMA P: Differences in thermoregulation between immunocompetent and immunodeficient hairless mice exposed to mild cold. Folia Microbiol (Praha) 43: 487-489, 1998.

GABALDÓN AM, FLOREZ-DUQUET ML, HAMILTON JS, MCDONALD RB, HORWITZ BA: Effects of age and gender on brown fat and skeletal muscle metabolic responses to cold in F344 rats. Am $J$ Physiol 268: R931-R941, 1995.

GASPARETTI AL, DE SOUZA CT, PEREIRA-DA-SILVA M, OLIVEIRA RL, SAAD MJ, CARNEIRO EM, VELLOSO LA: Cold exposure induces tissue-specific modulation of the insulin-signalling pathway in Rattus norvegicus. J Physiol 552: 149-162, 2003.

HOŠEK B, CHLUMECKÝ J, MISUSTOVÁ J: A comparison of energy exchange and thermal insulation in hairless and normal mice. Physiol Bohemoslov 14: 476-480, 1965.

HOUŠTĚK J, HOLUB M: Cold-induced changes in brown adipose tissue thermogenic capacity of immunocompetent and immunodeficient hairless mice. J Comp Physiol B 164: 459-463, 1994.

KIM S, KRYNYCKYI BR, MACHAC J, KIM CK: Temporal relation between temperature change and FDG uptake in brown adipose tissue. Eur J Nucl Med Mol Imaging 35: 984-989, 2008.

LIU X, ROSSMEISL M, MCCLAINE J, RIACHI M, HARPER ME, KOZAK LP: Paradoxical resistance to diet-induced obesity in UCP1-deficient mice. J Clin Invest 111: 399-407, 2003.

MARSILI A, AGUAYO-MAZZUCATO C, CHEN T, KUMAR A, CHUNG M, LUNSFORD EP, HARNEY JW, VAN-TRAN T, GIANETTI E, RAMADAN W, CHOU C, BONNER-WEIR S, LARSEN PR, SILVA JE, ZAVACKI AM: Mice with a targeted deletion of the type 2 deiodinase are insulin resistant and susceptible to diet induced obesity. PLoS One 6: e20832, 2011.

MEYER B, BAZZI H, ZÍDEK V, MUSILOVÁ A, PRAVENEC M, KURTZ TW, NURNBERG P, CHRISTIANO AM: A spontaneous mutation in the desmoglein 4 gene underlies hypotrichosis in a new lanceolate hair rat model. Differentiation 72: 541-547, 2004.

NADAL-CASELLAS A, PROENZA AM, LLADÓ I, GIANOTTI M: Effects of ovariectomy and 17- $\beta$ estradiol replacement on rat brown adipose tissue mitochondrial function. Steroids 76: 1051-1056, 2011.

NOOKAEW I, SVENSSON PA, JACOBSON P, JERNÅS M, TAUBE M, LARSSON I, ANDERSSON-ASSARSSON JC, SJÖSTRÖM L, FROGUEL P, WALLEY A, NIELSEN J, CARLSSON LM: Adipose tissue resting energy expenditure and expression of genes involved in mitochondrial function are higher in women than in men. $J$ Clin Endocrinol Metab 98: E370-E378, 2013.

ORAVA J, NUUTILA P, LIDELL ME, OIKONEN V, NOPONEN T, VILJANEN T, SCHEININ M, TAITTONEN M, NIEMI T, ENERBÄCK S, VIRTANEN KA: Different metabolic responses of human brown adipose tissue to activation by cold and insulin. Cell Metab 14: 272-279, 2011.

PFANNENBERG C, WERNER MK, RIPKENS S, STEF I, DECKERT A, SCHMADL M, REIMOLD M, HÄRING HU, CLAUSSEN CD, STEFAN N: Impact of age on the relationships of brown adipose tissue with gender and adiposity in humans. Diabetes 59: 1789-1793, 2010.

PRAVENEC M, KĽEN V, LANDA V, MLEJNEK P, MUSILOVÁ A, ŠILHAVÝ J, ŠIMÁKOVÁ M, ZÍDEK V: Recent progress in the genetics of spontaneously hypertensive rats. Physiol Res 63 (Suppl 1): S1-S8, 2014. 
QUEVEDO S, ROCA P, PICÓ C, PALOU A: Gender-associated differences in cold-induced UCP1 synthesis in rodent brown adipose tissue. Pflügers Arch 436: 689-695, 1998.

RODRIGUEZ E, MONJO M, RODRIGUEZ-CUENCA S, PUJOL E, AMENGUAL B, ROCA P, PALOU A: Genderual dimorphism in the adrenergic control of rat brown adipose tissue response to overfeeding. Pflügers Arch 442: 396-403, 2001.

RODRIGUEZ-CUENCA S, PUJOL E, JUSTO R, FRONTERA M, OLIVER J, GIANOTTI M, ROCA P: Genderdependent thermogenesis, differences in mitochondrial morphology and function, and adrenergic response in brown adipose tissue. $J$ Biol Chem 277: 42958-42963, 2002.

SHIBATA H, PERUSSE F, VALLERAND A, BUKOWIECKI LJ: Cold exposure reverses inhibitory effects of fasting on peripheral glucose uptake in rats. Am J Physiol 257: R96-R101, 1989.

SMITH OL: Insulin response in rats acutely exposed to cold. Can J Physiol Pharmacol 62: 924-927, 1984.

VALLERAND AL, PERUSSE F, BUKOWIECKI LJ: Cold exposure potentiates the effect of insulin on in vivo glucose uptake. Am J Physiol 253: E179-E186, 1987.

VAN DER LANS AA, HOEKS J, BRANS B, VIJGEN GH, VISSER MG, VOSSELMAN MJ, HANSEN J, JÖRGENSEN JA, WU J, MOTTAGHY FM, SCHRAUWEN P, VAN MARKEN LICHTENBELT WD: Cold acclimation recruits human brown fat and increases nonshivering thermogenesis. $J$ Clin Invest 123: 3395-3403, 2013.

VIJGEN GH, BOUVY ND, TEULE GJ, BRANS B, SCHRAUWEN P, VAN MARKEN LICHTENBELT WD: Brown adipose tissue in morbidly obese subjects. PLoS One 6: el18247, 2011.

VIRTANEN KA, LIDELL ME, ORAVA J, HEGLIND M, WESTERGREN R, NIEMI T, TAITTONEN M, LAINE J, SAVISTO NJ, ENERBÄCK S, NUUTILA P: Functional brown adipose tissue in healthy adults. $N$ Engl $J$ Med 360: 1518-1525, 2009.

VRÁNA A, POLEDNE R, FÁBRY P, KAZDOVÁ L: Palmitate and glucose oxidation by diaphragm of rats with fructose-induced hypertriglyceridemia. Metabolism 27: 885-888, 1978.

WEIHE WH: The thermoregulation of the nude mouse. Exp Cell Biol 52: 140-144, 1984.

WHITTLE AJ, LÓPEZ M, VIDAL-PUIG A: Using brown adipose tissue to treat obesity - the central issue. Trends Mol Med 17: 405-411, 2011.

YKI-JARVINEN H: Gender and insulin sensitivity. Metabolism 33: 1011-1015, 1984.

ZHOU Z, YON TOH S, CHEN Z, GUO K, NG CP, PONNIAH S, LIN SC, HONG W, LI P: Cidea-deficient mice have lean phenotype and are resistant to obesity. Nat Genet 35: 49-56, 2003. 